\title{
Preparation, in vitro and in vivo evaluation of algino-pectinate bioadhesive microspheres: An investigation of the effects of polymers using multiple comparison analysis
}

\author{
SANTANU CHAKRABORTY1,* \\ MADHUSMRUTI KHANDAI ${ }^{1}$ \\ ANURADHA SHARMA ${ }^{1}$ \\ NAZIA KHANAM ${ }^{1}$ \\ CH. NIRANJAN PATRA ${ }^{1}$ \\ SUBAS CHANDRA DINDA ${ }^{3}$ \\ KALYAN KUMAR SEN ${ }^{2}$ \\ ${ }^{1}$ P. G. Department of Pharmaceutics \\ College of Pharmaceutical Sciences \\ Berhampur-760002 Orissa, India \\ ${ }^{2}$ P. G. Department of Pharmaceutics \\ Gupta College of Technological Sciences \\ Asansol, West Bengal, India \\ 3 School of Pharmaceutical Education \\ and Research, Berhampur University \\ Bhanja Bihar, Berhampur-760007 \\ Orissa, India
}

Accepted July 12, 2010

\begin{abstract}
Ionotropic gelation was used to entrap aceclofenac into algino-pectinate bioadhesive microspheres as a potential drug carrier for the oral delivery of this anti-inflammatory drug. Microspheres were investigated in vitro for possible sustained drug release and their use in vivo as a gastroprotective system for aceclofenac. Polymer concentration and polymer/drug ratio were analyzed for their influence on microsphere properties. The microspheres exhibited good bioadhesive property and showed high drug entrapment efficiency. Drug release profiles exhibited faster release of aceclofenac from alginate microspheres whereas algino-pectinate microspheres showed prolonged release. Dunnet's multiple comparison analysis suggested a significant difference in percent inhibition of paw edema when the optimized formulation was compared to pure drug. It was concluded that the algino-pectinate bioadhesive formulations exhibit promising properties of a sustained release form for aceclofenac and that they provide distinct tissue protection in the stomach.
\end{abstract}

Keywords: algino-pectinate microspheres, aceclofenac, bioadhesion, ionotropic gelation, in vivo study

Aceclofenac (AC) is a phenyl acetic acid derivative [2-(2',6'-dichlorophenyl)amino] phenylacetoxyacetic acid], a novel NSAID indicated for the symptomatic treatment of pain and inflammation (1). The short biological half-life (about $4 \mathrm{~h}$ ) and high frequency of dosing make aceclofenac an ideal candidate for sustained release. The bioadhesive microspheres of aceclofenac would prolong the residence time at the absorption site to facilitate intimate contact with the absorption surface and thereby improve and enhance bioavailability and increase patient compliance. Natural hydrophilic polymers like alginate and pectin are widely used in numerous biomedical applications for their bioadhesion properties. Alginic acid and pectin are natural polysaccharides that are widely

*Correspondence; e-mail: santanu_nil@rediffmail.com 
S. Chakraborty et al.: Preparation, in vitro and in vivo evaluation of algino-pectinate bioadhesive microspheres: An investigation of the effects of polymers using multiple comparison analysis, Acta Pharm. 60 (2010) 255-266.

used as a vehicle for controlled drug delivery (2) due to their non-toxicity and low production cost. In general, microspheres, have the potential to be used for targeted and controlled-release drug delivery; but coupling of bioadhesive properties to microspheres has additional advantages, e.g., efficient absorption, a much more intimate contact with the mucus layer and specific targeting of the drug to the absorption site.

The objective of the present study was to design algino-pectinate bioadhesive microspheres of aceclofenac and evaluate the effect of polymer concentration on particle size, encapsulation efficacy, enteric nature and drug release kinetics. The ionotropic gelation technique was selected to prepare controlled release aceclofenac-loaded algino-pectinate microspheres due to its simplicity, low cost and its high entrapment rates achieved with poorly water-soluble drugs.

\section{EXPERIMENTAL}

\section{Materials}

Aceclofenac was a gift sample from Nicholas Primal India Ltd, India. Sodium alginate (viscosity $\approx 3.5 \mathrm{~Pa}$ s) was a gift from Signet Chemical Co, India. Pectin HM (high methoxylated, $M_{\mathrm{r}} 1.758 \times 10^{6}$ Dalton) was a gift from CP Kelco, Denmark. Commercial aceclofenac SR tablet $100 \mathrm{mg}$ (MKT) was purchased from Aristo, India. All other chemicals used were of analytical reagent grade.

\section{Preparation of microspheres}

Preparation of Na-alginate microspheres. - Na-alginate microspheres were prepared by ionic cross-linking (Table I). Sodium alginate was dissolved in distilled water to obtain different concentrations. Aceclofenac $(5 \%, \mathrm{~m} / \mathrm{m})$ was added to the sodium alginate solution and dispersed with an Ultraturrax (Jahnke and Kunkel, Germany) for 2 min at 8000 $\mathrm{rpm}$. This dispersion was added dropvise to a calcium chloride solution $(5 \%, \mathrm{~m} / \mathrm{m})$ using a $24 \mathrm{G}$ needle at a constant rate and under continuous stirring at $200 \mathrm{rpm}$. The stirring was continued for 30 minutes, for complete reaction. After 30 minutes, microspheres were collected by filtration, washed extensively with distilled water, and dried overnight at room temperature.

Preparation of Na-alginate microspheres with pectin. - Pectin and Na-alginate solutions of different concentrations (Table I) were separately prepared by dissolving both polymers in water under gentle agitation. Pectin solution was then added into Na-alginate solution and the mixture was stirred at $4000 \mathrm{rpm}$. Then, aceclofenac $(5 \%, \mathrm{~m} / \mathrm{m})$ was added to the polymer solution and dispersed with an Ultraturrax for $2 \mathrm{~min}$ at $8000 \mathrm{rpm}$. The remaining procedure was the same as for Na-alginate microspheres.

\section{Evaluation of microspheres}

Particle size. - Size and size distribution of microspheres were measured by sieve analysis (3). The microspheres were separated into different size fractions (\% mass frac- 
S. Chakraborty et al.: Preparation, in vitro and in vivo evaluation of algino-pectinate bioadhesive microspheres: An investigation of the effects of polymers using multiple comparison analysis, Acta Pharm. 60 (2010) 255-266.

tion) by sieving for 5 min using standard sieves with nominal mesh apertures of 1.4, 1.2, $1.0,0.85$ and $0.71 \mathrm{~mm}$ and the particle size of the microspheres was determined (Table I).

Microencapsulation efficiency. - The drug content in microspheres was determined by the reported method with a slight modification (4). The microspheres (100 mg) were allowed to disintegrate in $50 \mathrm{~mL}$ of phosphate buffer ( $\mathrm{pH} \mathrm{6.8)}$ for $4 \mathrm{~h}$. Dispersion of microspheres was sonicated at $125 \mathrm{~W}$ for $30 \mathrm{~min}$ (Imeco Sonifier, Imeco Ultrasonics, India) and the solution was filtered through a $0.45-\mu \mathrm{m}$ filter. Then, the polymeric debris was washed twice with fresh solvent (phosphate buffer) to extract any adhering drug. The drug content of the filtrate was determined spectrophotometrically at $273 \mathrm{~nm}$ (UV-2450, Shimadzu, Japan). Each determination was made in triplicate.

Micromeritic properties of microspheres. - The flow properties of microspheres were studied by determining the angle of repose, Carr's index (5), bulk density and tapped density. The angle of repose was determined by the fixed-base cone method. Bulk and tapped densities were determined using a digital bulk density apparatus (Electrolab, India). Each experiment was conducted in triplicate.

Enteric nature of microspheres. - The study was performed to observe whether the drug released from the polymeric matrices in the acidic environment of the stomach. Fifty milligrams of microspheres were soaked in $10 \mathrm{~mL}$ of $0.1 \mathrm{~mol} \mathrm{~L}^{-1} \mathrm{HCl}$ at $37 \pm 0.5^{\circ} \mathrm{C}$ in a water bath. After 2 hours, the sample was centrifuged (3000 rpm, 20 minutes). The supernatant was subjected to UV-scan at $273 \mathrm{~nm}$ and analyzed for aceclofenac concentration against $0.1 \mathrm{~mol} \mathrm{~L}^{-1} \mathrm{HCl}$ blank.

Scanning electron microscopy. - The sample was spread on a stub and coated for $120 \mathrm{~s}$ with a layer of gold using a sputter coater and placed in the scanning electron microscope (JSM 5610 LV SEM, JEOL, Japan) chamber at acceleration voltage of $20 \mathrm{kV}$, chamber pressure of $0.6 \mathrm{~mm} \mathrm{Hg}$. Photographs were taken at different magnifications (Fig. 1).

Bioadhesive property of microspheres. - The bioadhesive property of the microspheres was evaluated employing the method described by Lehr et al. (6). The test was performed in both simulated gastric fluid $\left(0.1 \mathrm{~mol} \mathrm{~L}^{-1} \mathrm{HCl}, \mathrm{pH} 1.2\right)$ and simulated intestinal fluid (phosphate buffer, $\mathrm{pH}$ 6.8). Freshly excised pieces of goat intestinal mucosa $(2 \times 3$ $\mathrm{cm}$ ) were mounted onto glass slides with cyanoacrylate glue. About 50 microspheres were spread onto each wet rinsed tissue specimen and immediately thereafter the slides with suitable support were hung onto the arm of a USP tablet disintegrating test machine. The tissue specimen was given a slow, regular up-and-down movement in the test fluid at $37^{\circ} \mathrm{C}$ contained in a one liter vessel. At different time intervals (up to $8 \mathrm{~h}$ ), the number of microspheres still adhering to the tissue was counted.

FTIR. - The FTIR study was carried out using Prestige-21, Shimadzu, Japan. The pure drug sample, pure polymers and formulations containing both drug and polymer were scanned to study the possible drug and polymer interaction.

\section{In vitro drug release study}

Release of aceclofenac was determined using a USP six stage dissolution rate test apparatus I (7) (Thermolab ${ }^{\circledR}$, India) at $50 \mathrm{rpm}$. An accurately weighed aliquot of micro- 
S. Chakraborty et al.: Preparation, in vitro and in vivo evaluation of algino-pectinate bioadhesive microspheres: An investigation of the effects of polymers using multiple comparison analysis, Acta Pharm. 60 (2010) 255-266.

particles equivalent to $100 \mathrm{mg}$ of aceclofenac was added into each dissolution flask. Dissolution was studied using $900 \mathrm{~mL}$ of phosphate buffer $(\mathrm{pH}$ 6.8). The temperature was maintained at $37 \pm 0.2{ }^{\circ} \mathrm{C}$. Samples of $5 \mathrm{~mL}$ each were withdrawn at different time intervals, filtered through a Whatman filter membrane No. $1(0.45 \mu \mathrm{m})$ (Auroco Pvt. Ltd, Thailand) and replaced with an equal amount of fresh dissolution medium. Samples were suitably diluted and analyzed for aceclofenac at $273 \mathrm{~nm}$. The amount of aceclofenac was calculated from the calibration curve. Release studies were conducted in triplicate.

\section{Release profiles}

The rate and mechanism of drug release from the prepared microspheres were analyzed by fitting the dissolution data into the zero-order equation:

$$
\mathrm{Q}=k_{0} t
$$

where $Q$ is the amount of drug released at time $t$ and $k_{0}$ is the release rate constant, first-order equation:

$$
\ln (100-Q)=\ln 100-k_{1} t
$$

where $k_{1}$ is the release rate constant, Higuchi's equation (8):

$$
Q=k_{2} t^{1 / 2}
$$

where $k_{2}$ is the diffusion rate constant.

The drug release data was further analyzed by the Korsmeyer-Peppas equation (9):

$$
\frac{M_{t}}{M_{\infty}}=k t^{n}
$$

where $n$ is the release exponent indicative of the release mechanism, $M_{t} / M_{\infty}$ is the fractional release of the drug, $t$ is the release time, $k$ is the kinetic constant.

\section{Preliminary anti-inflammatory activity study}

The preclinical study (anti-inflammatory study) was carried out on male Wistar rats (weighing 180-200 g) obtained from the Central Animal House, College of Pharmaceutical Sciences, Berhampur, India. They were housed in elevated wire cages, 4 animals per cage, with free access to food (Lipton Feed, India) and water. The preclinical study protocol was approved by the Institutional Animal Ethical Committee, College of Pharmaceutical Sciences, Berhampur, India.

Carrageenean-induced rat paw edema model was used to assess the anti-inflammatory effect of the pure drug, optimized microsphere formulation (F7) and commercial 
S. Chakraborty et al.: Preparation, in vitro and in vivo evaluation of algino-pectinate bioadhesive microspheres: An investigation of the effects of polymers using multiple comparison analysis, Acta Pharm. 60 (2010) 255-266.

aceclofenac SR tablet (10). Overnight fasted animals were divided into 4 groups $(n=6)$ and treated as follows: group I (control): $2.5 \mathrm{~mL}$ of $0.5 \%$ sodium carboxymethylcellulose (CMC), p.o.; group II: pure aceclofenac $\left(10 \mathrm{mg} \mathrm{kg}^{-1}\right)$ in $0.5 \% \mathrm{CMC}$, p.o.; group III: optimized algino-pectinate microsphere (F7) $\left(10 \mathrm{mg} \mathrm{kg}^{-1}\right)$ in $0.5 \% \mathrm{CMC}$, p.o.; group IV: commercial SR tablet (MKT) (Aristo, India) $\left(10 \mathrm{mg} \mathrm{kg}^{-1}\right)$ in $0.5 \% \mathrm{CMC}$, p.o. After $30 \mathrm{~min}$ of drug administration, rats of all groups were challenged by a subcutaneous injection of $0.05 \mathrm{~mL}$ of $1 \%$ solution of carrageenean in saline into the plantar site of the left hind paw. Paw volumes were measured at different time intervals with a plethysmometer (INCO, India) prior to carrageenean administration. The percent inhibition of edema for all time intervals was then calculated.

\section{Statistical analysis}

In vitro drug release data was subjected to one-way analysis of variance (one-way ANOVA). Statistical analysis of the data was performed using the PRISM software (Graph pad, San Diego, CA, USA). In vivo data (\% inhibition) was subjected to one-way ANOVA followed by Dunnett's multiple comparison test to find out whether any significant difference was present between commercial formulation and the optimized microsphere formulation.

\section{RESULTS AND DISCUSSION}

\section{Physicochemical characterization of microspheres}

The yield was $93.1 \pm 2.8 \%$ (range 88.3 to $95.7 \%$ ), particle size of the microspheres was $0.72 \pm 0.07 \mathrm{~mm}$ (range $0.61-0.81 \mathrm{~mm}$ ) and entrapment efficiency was found to be $85.4 \pm 1.8 \%$ (range 73.2 to $96.9 \%$ ). Table I summarizes the data for all formulation. It was found that by increasing the polymer concentration, particle size as well as encapsulation efficiency of microspheres increased. This may be due to higher polymer concen-

Table I. Characterization of prepared microspheres

\begin{tabular}{ccccc}
\hline Formulation & $\begin{array}{c}\text { Polymer level } \\
(\%, m / V)\end{array}$ & $\begin{array}{c}\text { Yield } \\
(\%)^{\mathrm{a}}\end{array}$ & $\begin{array}{c}\text { Encapsulation } \\
\text { efficiency }(\%)^{\mathrm{a}}\end{array}$ & $\begin{array}{c}\text { Particle size } \\
(\mathrm{mm})^{\mathrm{a}}\end{array}$ \\
\hline F1 & Sodium alginate (1) & $88.3 \pm 2.3$ & $73.2 \pm 2.1$ & $0.61 \pm 0.02$ \\
F2 & Sodium alginate (2) & $90.1 \pm 2.4$ & $77.2 \pm 1.5$ & $0.67 \pm 0.04$ \\
F3 & Sodium alginate (3) & $93.4 \pm 3.2$ & $82.5 \pm 1.7$ & $0.70 \pm 0.05$ \\
F4 & Sodium alginate (4) & $92.2 \pm 2.9$ & $84.6 \pm 1.6$ & $0.72 \pm 0.11$ \\
F5 & Sodium alginate (1) + pectin (1) & $95.5 \pm 3.4$ & $86.1 \pm 2.9$ & $0.74 \pm 0.05$ \\
F6 & Sodium alginate (1) + pectin (2) & $94.5 \pm 2.0$ & $89.7 \pm 1.5$ & $0.81 \pm 0.08$ \\
F7 & Sodium alginate (1) + pectin (3) & $95.7 \pm 3.6$ & $93.2 \pm 2.2$ & $0.75 \pm 0.14$ \\
F8 & Sodium alginate (1) + pectin (4) & $94.7 \pm 2.9$ & $96.9 \pm 1.1$ & $0.79 \pm 0.07$ \\
\hline
\end{tabular}

a Mean $\pm \mathrm{SD}, n=3$. 
S. Chakraborty et al.: Preparation, in vitro and in vivo evaluation of algino-pectinate bioadhesive microspheres: An investigation of the effects of polymers using multiple comparison analysis, Acta Pharm. 60 (2010) 255-266.

tration, which increases the viscosity of the medium and makes greater availability of calcium binding sites in polymeric chains. As a result, the degree of cross-linking increased and larger droplets were formed, entrapping a higher amount of the drug.

\section{Micromeritic properties of microspheres}

The angle of repose and Carr's index of the pure drug were found to be $39.4 \pm 1.1^{\circ}$ and $32.6 \pm 1.7$, which indicate a poor flow property. The angle of repose and Carr's index of the prepared microspheres were $17.2 \pm 1.3^{\circ}\left(14.7\right.$ to $\left.19.4^{\circ}\right)$ and $8.5 \pm 7.0$ (2.7 to 23.4 ), respectively (Table II). Bulk density of the formulations was found to be $0.40 \pm 0.09 \mathrm{~g} \mathrm{~mL}^{-1}$ (range 0.21 to $0.79 \mathrm{~g} \mathrm{~mL}^{-1}$ ) and tapped density was found to be $0.39 \pm 0.07 \mathrm{~g} \mathrm{~mL}^{-1}(0.17$ to $\left.0.67 \mathrm{~g} \mathrm{~mL}^{-1}\right)$. The micromeritic study showed that the prepared microspheres had a good flow property, excellent compressibility, good packability compared to the pure drug.

\section{Enteric nature of microspheres}

Aceclofenac exists in its acidic form which is practically insoluble in the stomach $\mathrm{pH}$ (11). Due to this fact and in an attempt to reduce side effects, the enteric nature of the microspheres was evaluated in order to find out whether the prepared formulations were able to restrict the drug release in an acidic environment. Na-alginate microspheres and algino-pectinate microspheres were able to restrict the drug release in acidic medium, but some amount of drug was found to be released at stomach $\mathrm{pH}$. It was observed that a much lower amount of aceclofenac was released in the acidic environment $5.2 \%$ drug) from Na-alginate microspheres in $0.1 \mathrm{~mol} \mathrm{~L}^{-1} \mathrm{HCl}$ medium, $\mathrm{pH} 1.2$, in 2 hours but $2.2 \%$ in the case of algino-pectinate microspheres. This may be attributed to the fact that aceclofenac, which is present on the surface of microspheres, immediately comes in contact with the medium (12). Thus these formulations could protect the acid-labile drug and enzyme from gastric degradation (13).

Table II. Micromeritic evaluation of prepared microspheres

\begin{tabular}{ccccc}
\hline Formulation & $\begin{array}{c}\text { Bulk density } \\
\left.(\mathrm{g} \mathrm{mL})^{-1}\right)^{\mathrm{a}}\end{array}$ & $\begin{array}{c}\text { Tapped density } \\
\left(\mathrm{g} \mathrm{mL}^{-1}\right)^{\mathrm{a}}\end{array}$ & $\begin{array}{c}\text { Angle of repose } \\
\left({ }^{\circ}\right)^{\mathrm{a}}\end{array}$ & Carr's index $^{\mathrm{a}}$ \\
\hline PD & $0.81 \pm 0.09$ & $0.73 \pm 0.08$ & $39.4 \pm 1.1$ & $32.6 \pm 1.7$ \\
F1 & $0.79 \pm 0.21$ & $0.67 \pm 0.14$ & $19.2 \pm 1.1$ & $23.4 \pm 1.3$ \\
F2 & $0.64 \pm 0.11$ & $0.59 \pm 0.07$ & $17.9 \pm 0.3$ & $12.1 \pm 1.9$ \\
F3 & $0.51 \pm 0.09$ & $0.45 \pm 0.04$ & $19.4 \pm 1.2$ & $10.0 \pm 0.8$ \\
F4 & $0.33 \pm 0.06$ & $0.49 \pm 0.07$ & $16.8 \pm 1.4$ & $8.7 \pm 1.1$ \\
F5 & $0.23 \pm 0.03$ & $0.33 \pm 0.06$ & $14.7 \pm 2.1$ & $4.2 \pm 0.8$ \\
F6 & $0.25 \pm 0.07$ & $0.22 \pm 0.08$ & $17.8 \pm 1.3$ & $3.6 \pm 0.3$ \\
F7 & $0.22 \pm 0.07$ & $0.19 \pm 0.05$ & $16.3 \pm 2.1$ & $3.4 \pm 0.9$ \\
F8 & $0.21 \pm 0.08$ & $0.17 \pm 0.08$ & $15.6 \pm 1.2$ & $2.7 \pm 0.3$ \\
\hline
\end{tabular}

$\mathrm{PD}$ - pure drug, ${ }^{a}$ Mean $\pm \mathrm{SD}, n=3$. 
S. Chakraborty et al.: Preparation, in vitro and in vivo evaluation of algino-pectinate bioadhesive microspheres: An investigation of the effects of polymers using multiple comparison analysis, Acta Pharm. 60 (2010) 255-266.

\section{Scanning electron micrograpy}

Scanning electron micrographs (SEM) of the microspheres are shown in Fig. 1. The SEM results revealed that all the aceclofenac loaded microspheres were discrete and spherical in shape, with a rough outer surface. The surface of the microspheres was rough due to the density of the polymer matrix, which in turn justified its sustained release.

\section{Bioadhesive property of microspheres}

All the microspheres exhibited good bioadhesive properties, as observed in the in vitro wash-off test. It was found that both $\mathrm{Na}$-alginate and algino-pectinate microspheres had less bioadhesion in simulated gastric fluid $(\mathrm{pH} 1.2)$ compared to simulated intestinal fluid ( $\mathrm{pH}$ 6.8). This may be due to the fact that Na-alginate is practically insoluble in aqueous acidic solution whereas in simulated intestinal fluid its solubility, hydration and bioadhesivity property were increased due to ionization of the carboxyl acid group and other functional groups present in the polymer. This increased solubility allowed more solvent to penetrate the polymeric coat, produce a viscous gel and increase the bioadhesion property.

It was also observed that algino-pectinate microspheres had a better bioadhesive property (Fig. 2) than alginate microspheres, because a combination of both polymers increases the viscosity of the matrix, which helps in increasing adhesion to intestinal mucosa. Adhesion of the microspheres to the intestine mucosa for a prolonged period is suggested where they release the drug in a sustained manner.

Fig. 1. Scanning electron photomicrographs of the algino-pectinate microspheres (F7): a) $50 \mathrm{X}, \mathrm{b}) 100 \mathrm{X}, \mathrm{c}) 200 \mathrm{X}, \mathrm{d})$ $750 \mathrm{X}$.
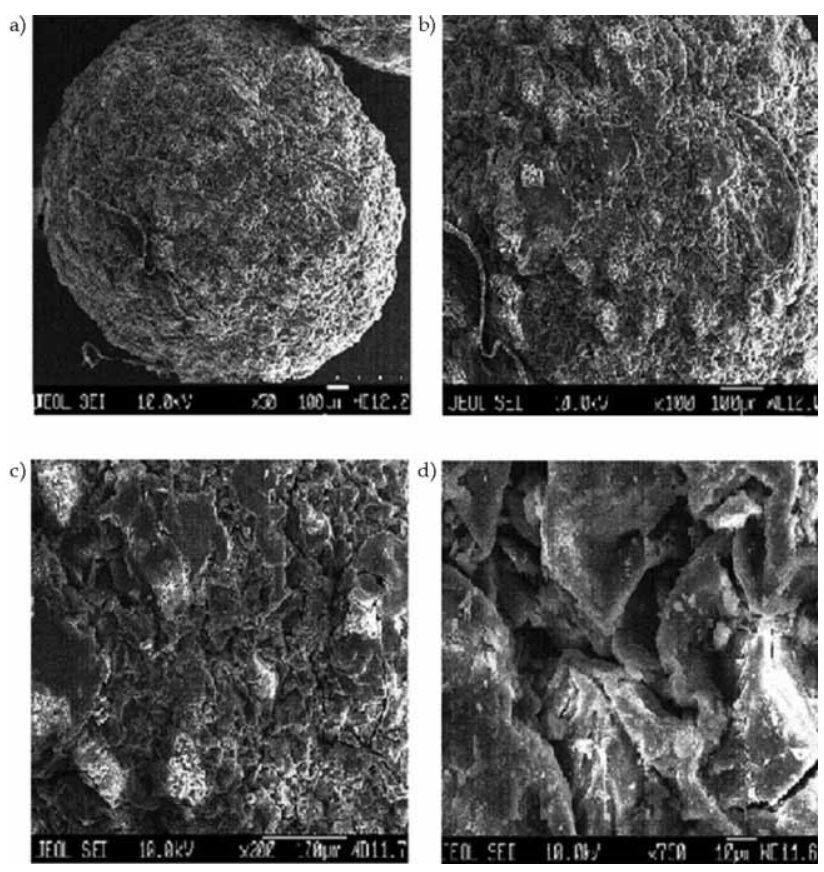
S. Chakraborty et al.: Preparation, in vitro and in vivo evaluation of algino-pectinate bioadhesive microspheres: An investigation of the effects of polymers using multiple comparison analysis, Acta Pharm. 60 (2010) 255-266.

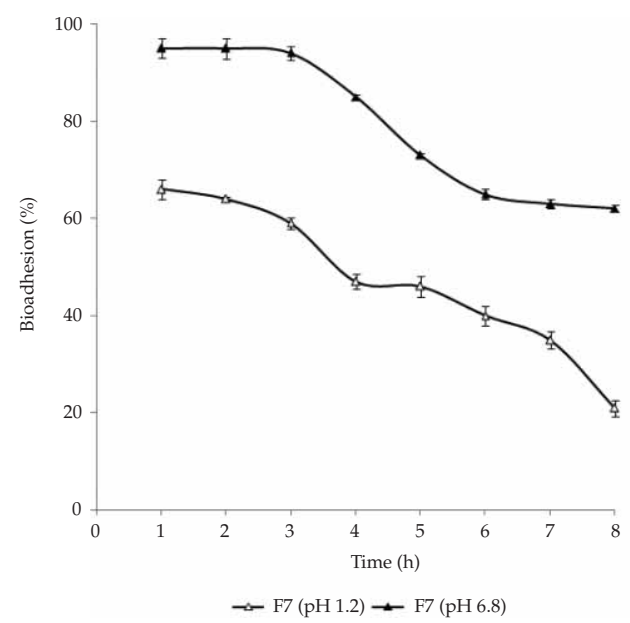

Fig. 2. Bioadhesion behavior of algino-pectinate optimized formulation (F7) (mean \pm $\mathrm{SD}, n=3)$ in $0.1 \mathrm{~mol} \mathrm{~L}^{-1} \mathrm{HCl}(\mathrm{pH} \mathrm{1.2)}$ ) and in phosphate buffer ( $\mathrm{pH}$ 6.8).

\section{FTIR}

FTIR spectra are shown in Fig. 3. Pure aceclofenac showed different peaks at 3319.2, $3278.9,1771.7,1716.8,1589.4,1508.1,1344.3,1280.6,1149.4$ and $1055.8 \mathrm{~cm}^{-1}$. Among them some major peaks are 3319.2 for stretching vibration of $\mathrm{OH}$ of $\mathrm{COOH}$ group, 3278.9 for stretching vibration of $\mathrm{NH}$ group, 1716.8 for stretching vibration of $\mathrm{C}=\mathrm{O}$ attached to the methylene group and ether, 1280.6 for C-N stretching vibration of secondary aromatic amine, 1149.4 for aliphatic ether (asymmetric C-O-C stretching), 1055.8 for $\mathrm{OH}$ bending vibration. In the optimized formulation (F7), all the above mentioned peaks were intact

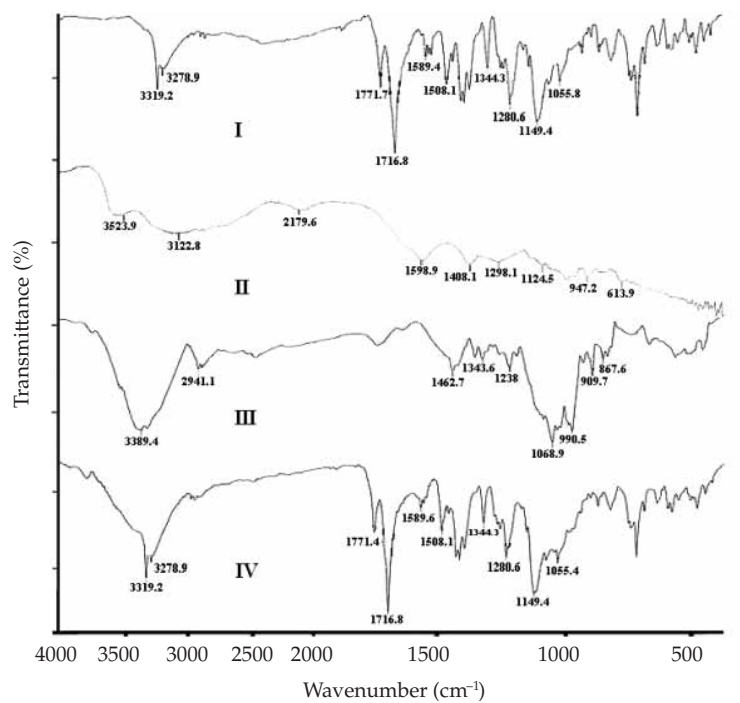

Fig. 3. FT-IR spectra of pure aceclofenac (I), Na-alginate (II), pectin (III), optimized formulation F7 (IV). 
S. Chakraborty et al.: Preparation, in vitro and in vivo evaluation of algino-pectinate bioadhesive microspheres: An investigation of the effects of polymers using multiple comparison analysis, Acta Pharm. 60 (2010) 255-266.

and no considerable changes in the IR peaks were observed. FTIR spectra thus indicate the stable nature of aceclofenac in the prepared formulations.

\section{In vitro drug release study}

The effect of the polymer level on the release of AC from the microspheres was studied (F1-F8). Formulations F1, F2, F3 and F4 were able to sustain the drug release for 4, 5, 7 and 8 hours, respectively, whereas algino-pectinate microspheres (F5 to F7) were able to sustain the drug release for 10 to 12 hours (Fig. 4). On increasing the quantity of pectin up to $4 \%(\mathrm{~m} / \mathrm{V})$, the release of the drug was too slow and only $68.3 \%$ of the drug

Fig. 4. Cumulative drug released vs. time (mean $\pm \mathrm{SD}, n=3$ ) from pure drug (PD) to F8.

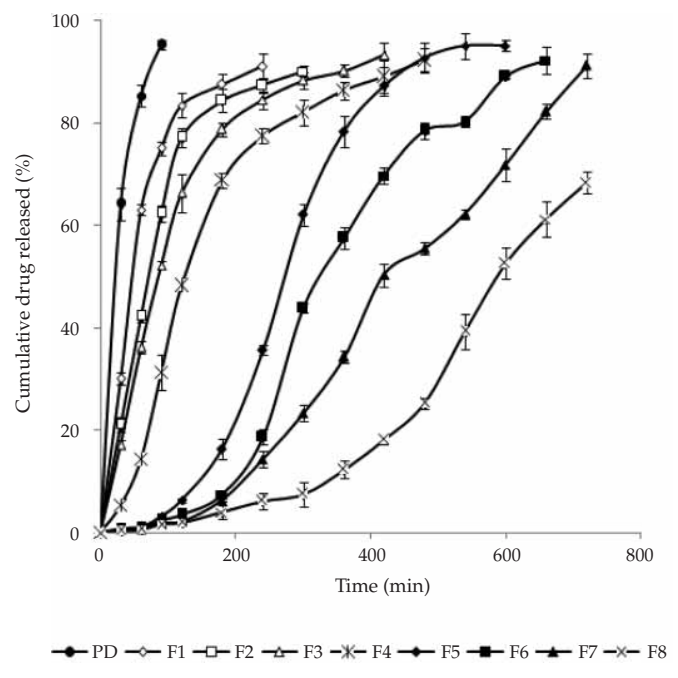

Table III. Kinetics of drug release from aceclofenac microspheres

\begin{tabular}{cccccc}
\hline \multicolumn{5}{c}{ Drug release kinetics } \\
\hline Formulation & $\begin{array}{c}\text { Higuchi } \\
\left(R^{2}\right)\end{array}$ & $\begin{array}{c}\text { Higuchi rate } \\
\text { constant }\left(k_{\mathrm{h}}\right. \\
\left.\mathrm{mg} \mathrm{h}^{-1 / 2}\right)\end{array}$ & $\begin{array}{c}\text { Korsmeyer- } \\
\text {-Peppas }\left(R^{2}\right)\end{array}$ & $\begin{array}{c}\text { Release } \\
\text { exponent }(n)\end{array}$ & $t_{50}(\mathrm{~h})$ \\
\hline F1 & 0.924 & 6.342 & 1.000 & 0.918 & 0.80 \\
F2 & 0.934 & 5.787 & 0.999 & 0.908 & 1.18 \\
F3 & 0.944 & 4.985 & 0.996 & 0.873 & 1.40 \\
F4 & 0.926 & 4.890 & 0.996 & 0.759 & 2.05 \\
F5 & 0.895 & 6.448 & 0.956 & 0.527 & 4.65 \\
F6 & 0.906 & 5.479 & 0.930 & 0.657 & 5.87 \\
F7 & 0.891 & 4.063 & 0.955 & 0.733 & 6.99 \\
F8 & 0.736 & 2.302 & 0.963 & 0.689 & 9.87 \\
\hline
\end{tabular}


was released after 12 hours. Formulations containing Na-alginate alone (F1 to F4) underwent erosion before complete swelling could take place, resulting in faster drug release. It was also observed that at acidic $\mathrm{pH}$ drug release was extremely slow and increased in phosphate buffer. This is because at acidic $\mathrm{pH}$, alginate microspheres shrink due to the tightening of gel meshwork, whereas at $\mathrm{pH} 6.8$ alginate errodes and releases the contents in a sustained manner (14). Algino-pectinate microspheres (F5 to F8) were more efficient in sustaining the drug release compared to alginate microspheres (F1-F4) because pectin could form a rigid coat with calcium ions (15), thus forming a calcium-pectinate gel matrix. Free carboxyl groups in the HM pectin molecule are distributed block-wise; therefore the gelation of this pectin is possible because of the "egg-box " structure, resulting from chelation of calcium ions in electronegative cavities formed by the carboxyl residues and hydroxyl groups (16). One way analysis of variance suggested that a significant difference at $p<0.05$ was present among all the formulations F1 to F8 with respect to in vitro drug release. Among all the formulations, F7 showed the best dissolution profile (more than $90 \%$ drug was released in 12 hours), so it was selected for the in vivo study.

The coefficient of determination $\left(R^{2}\right)$ was used as an indicator of the best fitting for each of the models considered (Table III). Kinetic data of all the formulations reached a higher coefficient of determination $\left(R^{2}=0.963-1.000\right)$ with the Korsmeyer-Peppas model whereas the release exponent value $(n)$ ranged from 0.527 to 0.918 . The release exponent in the Korsmeyer-Peppas model suggested that the mechanism that led to the release of aceclofenac was an anomalous non-Fickian diffusion mechanism pointing to the conclusion that a combined release mechanism of drug diffusion and sphere erosion might be appropriate.

\section{Preliminary anti-inflammatory activity study}

Inhibition of rat paw edema at each time point was calculated (Table IV). Pure drug exhibited comparatively rapid anti-inflammatory activity. Inhibition values of the pure drug were higher than those of test and commercial formulations. In the case of F7 and commercial SR tablet the inhibition effect was slowly attained. However, at the end of

Table IV. Anti-inflammatory activity of bioadhesive algino-pectinate microspheres

\begin{tabular}{cccc}
\hline \multirow{2}{*}{ Time $(\mathrm{h})$} & \multicolumn{3}{c}{ Inhibition $(\%)^{\mathrm{a}}$} \\
\cline { 2 - 4 } & $\mathrm{PD}^{\mathrm{b}}$ & $\mathrm{F}^{\mathrm{b}}$ & $\mathrm{MKT}^{\mathrm{b}}$ \\
\hline 1 & $29.0 \pm 1.2$ & $10.3 \pm 2.1^{\mathrm{c}}$ & $45.6 \pm 3.2^{\mathrm{c}}$ \\
2 & $49.0 \pm 2.1$ & $30.6 \pm 0.9^{\mathrm{c}}$ & $61.7 \pm 2.5^{\mathrm{c}}$ \\
3 & $69.6 \pm 2.1$ & $51.8 \pm 3.2^{\mathrm{c}}$ & $73.9 \pm 0.7^{\mathrm{c}}$ \\
4 & $73.6 \pm 2.1$ & $67.7 \pm 2.7^{\mathrm{c}}$ & $80.6 \pm 2.6^{\mathrm{c}}$ \\
5 & $72.3 \pm 1.0$ & $76.3 \pm 1.9^{\mathrm{c}}$ & $82.3 \pm 0.8^{\mathrm{c}}$ \\
\hline
\end{tabular}

a Dose: $10 \mathrm{mg} \mathrm{kg}^{-1}$.

b Mean \pm SD, $n=6$. PD - pure aceclofenac, F7 - optimized formulation, MKT - commercial aceclofenac SR tablet $(100 \mathrm{mg})$.

c Significant difference compared to PD $(p<0.05)$. 
S. Chakraborty et al.: Preparation, in vitro and in vivo evaluation of algino-pectinate bioadhesive microspheres: An investigation of the effects of polymers using multiple comparison analysis, Acta Pharm. 60 (2010) 255-266.

experiment, both exhibited highest anti-inflammatory activity at a dose level of $10 \mathrm{mg}$ $\mathrm{kg}^{-1}(76.3 \pm 1.9 \%$ in case of formulation F7 and $82.3 \pm 0.8 \%$ inhibition in case of commercial SR tablet). Both F7 and commercial formulations restricted drug release in the stomach and gradually increased the release when they entered the intestine. Dunnett's test suggested a significant difference for percent inhibition when the optimized formulation F7 was compared with the pure drug but no such event was observed when compared with the commercial aceclofenac SR tablet. The results indicate that the prepared microspheres F7 and commercial SR tablet produce sustained action of aceclofenac.

\section{CONCLUSIONS}

In conclusion, the algino-pectinate formulations exhibit promising properties of a controlled release form for aceclofenac. Theoretical models of the drug release indicated that drug release from the microspheres was triggered by matrix disintegration followed by swelling and relaxation of the polymer chain. In vivo data showed a significant difference for percent inhibition when the optimized formulation was compared with the pure drug.

\section{REFERENCES}

1. The Merck Index, $14^{\text {th }}$ ed., Merck \& Co., Inc., Whitehouse Station 2006.

2. R. Bodmeier and J. Wang, Microencapsulation of drugs with aqueous colloidal polymer dispersions, J. Pharm. Sci. 82 (1993) 191-194; DOI: 10.1002/jps.2600820215.

3. V. N. Badri, P. A. Thomas, J. K. Pandit, M. G. Kulkarni and R. A. Mashelkar, Preparation of non-porous microspheres with high entrapment of proteins by a (water-in-oil)-in-oil emulsion technique, J. Control. Rel. 58 (1999) 9-20; DOI: 10.1016/S0168-3659(98)00140-0.

4. S. A. Agnihotri, S. S. Jawalkar and T. M. Aminabhavi, Controlled release of cephalexin through gellan gum beads: Effect of formulation parameters on entrapment efficiency, size, and drug release, Eur. J. Pharm. Biopharm. 63 (2006) 249-261; DOI: 10.1016/j.ejpb.2005.12.008.

5. M. E. Aulton, Pharmaceutics, The Science of Dosage Form Design, $2^{\text {nd }}$ ed., Churchill Livingstone, New York 2002.

6. C. M. Lehr, J. A. Bowstra, J. J. Tukker and H. E. Junginger, Intestinal transit of bioadhesive microspheres in an in situ loop in the rat - A comparative study with copolymers and blends based on poly(acrylic acid), J. Control. Rel. 13 (1990) 51-62; DOI: 10.1016/01683659(90)90074-4.

7. US Pharmacopoeia 30, National Formulary 25, USP Convention, Rockville 2007.

8. T. Higuchi, Mechanism of sustained-action medication. Theoretical analysis of rate of release of solid drugs dispersed in solid matrices, J. Pharm. Sci. 52 (1963) 1145-1149; DOI: 10.1002/jps. 2600521210.

9. R. W. Korsmeyer, R. Gurny, E. Docler, P. Buri and N. A. Peppas, Mechanism of solute release from porous hydrophilic polymers, Int. J. Pharm. 15 (1983) 25-35; DOI: 10.1016/0378-5173(83) 90064-9.

10. S. K. Kulkarni, Handbook of Experimental Pharmacology, $2^{\text {nd }}$ ed., Vallabh Prakashan, New Delhi 1997.

11. M. Sheu, H. Chou, C. Kao, C. Liu and T. D. Sokoloski, Dissolution of diclofenac sodium from matrix tablets, Int. J. Pharm. 85 (1992) 57-63; DOI: 10.1016/0378-5173(92)90134-N. 
S. Chakraborty et al.: Preparation, in vitro and in vivo evaluation of algino-pectinate bioadhesive microspheres: An investigation of the effects of polymers using multiple comparison analysis, Acta Pharm. 60 (2010) 255-266.

12. M. Rawat, S. Saraf and S. Saraf, Influence of selected formulation variables on the preparation of enzyme-entrapped eudragit S100 microspheres, AAPS PharmSciTech 4 (2007) 1-9; DOI: 10.1208/ pt0804116.

13. P. Liu and T. R. Krishnan, Alginate-pectin-poly-L-lysine particulate as a potential controlled release formulation, J. Pharm. Pharmacol. 51 (1999) 141-149; DOI: 10.1211/0022357991772259.

14. A. Nascimento, M. C. M. Laranjeira, V. T. Favere and A. Josue, Impregnation and release of aspirin from chitosan/poly-(acrylic acid) graft copolymer microspheres, J. Microencapsul. 18 (2001) 679-84; DOI: 10.1080/02652040010019451.

15. C. Rolin, Pectin, in Industrial Gums: Polysaccharides and Their Derivatives (Eds. R. L. Whistler and J. N. Bemiller), Academic Press, New York 1993, pp. 257-293.

16. S. F. Ahrabi, G. Madsen, K. Dyrstad, S. A. Sande and C. Graffner, Development of pectin matrix tablets for colonic delivery of model drug ropivacaine, Eur. J. Pharm. Sci. 10 (2000) 43-52; DOI: 10.1016/S0928-0987(99)00087-1.

\section{$S A \check{Z} E T A K$}

Priprava, in vitro i in vivo evaluacija bioadhezivnih mikrosfera s algino-pektinom: Ispitivanje utjecaja polimera pomoću multiple poredbene analize

SANTANU CHAKRABORTY, MADHUSMRUTI KHANDAI, ANURADHA SHARMA, NAZIA KHANAM, CH. NIRANJAN PATRA, SUBAS CHANDRA DINDA i KALYAN KUMAR SEN

U radu je opisana priprava algino-pektinskih bioadhezivnih mikrosfera protuupalnog lijeka aceklofenaka metodom ionotropnog geliranja. In vitro je ispitivana mogućnost postupnog oslobađanja ljekovite tvari iz mikrosfera te mogućnost upotrebe mikrosfera kao gastroprotektivnog sustava za isporuku aceklofenaka in vivo. Ispitivan je utjecaj koncentracije polimera i omjera polimera i lijeka na svojstva mikrosfera. Mikrosfere su bile bioahezivne i sadržavale su veliki udio lijeka. Oslobađanje aceklofenaka iz alginatnih mikrosfera bilo je brže, a iz mikrosfera s algino-pektinom usporeno. Dunnetova multipla analiza ukazuje na značajnu razliku u postotku inhibicije edema šape kada se usporede optimizirana formulacija i čista ljekovita tvar. Može se zaključiti da su bioadhezivne mikrosfere s algino-pektinom povoljne za usporeno oslobađanje aceklofenaka te da pružaju umjerenu zaštitu sluznice želuca.

Ključne riječi: mikrosfere s algino-pektinom, aceklofenak, bioadhezija, ionotropno geliranje, ispitivanje in vivo

P. G. Department of Pharmaceutics, College of Pharmaceutical Sciences, Berhampur-760002 Orissa, India

P. G. Department of Pharmaceutics, Gupta College of Technological Sciences, Asansol, West Bengal, India 